\title{
Electronic Portfolio increases both Validating Skills and Employability \\ By
}

\author{
Dr. Mustafa Jwaifell
}

PhD: Instructional Technology

Al-Hussein Bin Talal University

Jordan

\begin{abstract}
The use of electronic portfolios in higher education has significantly increased in the last few years, especially in the United States of America, Canada, Europe and Australia rather than the Arabian universities. Electronic portfolios have a greater potential to alter higher education at its very core than any other technology. Both teachers and students can develop their own Electronic Portfolios; for teachers can adapt a new standardized evaluation methodology instead of traditional exams, while students can develop and share their skills life long.
\end{abstract}

\section{Introduction:}

The use of electronic portfolios in higher education has begun to receive increasing attention. Institutions such as the American Association of Colleges and Universities have focused on Portfolios in courses, programs, learning outcomes, and 
student evaluation. Colleges of Education, have a long history of accreditation reviews and standards for content areas as well as professional standards for teachers. Funding issues and competition in the college market are driving Colleges of Education to gather data in large quantities that showcase their graduates for future employment opportunities (Franklin, 2005). Electronic Portfolios serve as a mean of authentic assessment to demonstrate a teacher's proficiency as well as students.

In the Arab world, unfortunately, educational institutions still lack some of the basic skills and knowledge needed to work with technology in their classrooms, to model the effective use of technology, and give opportunities to their students to show and gain skills that qualified them to increase their employability, while electronic portfolio with its different types allow flexibility so that the teacher can measure a specific skill of his own students. The portfolio assessment is the systematic collection of the student's work measured against predetermined scoring criteria. These criteria may include scoring guides, rubrics, or rating scales (O'Mailley \& Pierce in Gomez, 2000).

Some emerging research suggests that electronic portfolios can help students learn how to develop their identities as being professionals (Alvarez \& Moxley, 2004; Schatz \& Simon, 1999; Schatz, 2004). Thus portfolios can be applied in the educational settings for a variety of purposes such as evaluation and assessment, career development, and for demonstrating students' learning experience and growth over time.

\section{Definition of Electronic Portfolio:}

Electronic portfolio can be: digital presentations of skills and competences, online records of achievement, and action plans with opportunities for reflection; all these have been in use in education for nearly a decade. Tools and systems built for these purposes are now numerous. Many institutions view the electronic portfolio as a 
replacement for traditional high stake assessment, the object of the exercise being coverage of all standards and criteria. In some institutions, the emphasis on enhancing online résumés, really misses out being on major benefits of the electronic portfolio such as, 'power in the process' and reflective thought leading to deep learning. You do obtain tangible products throughout the 'process,' examples include online résumés; however intangible products are arguably more important in a system designed to facilitate learning (Tosh \& Werdmuller. 2004).

Electronic portfolio can be used more than an assessment or learning tool, it can be used as a life-long learning and collaborating tool. In this point of view, many definitions take place in the literature. However, there is a distinction between electronic and digital portfolio: an Electronic Portfolio contains artifacts that may be in analog form, such as a video tape, or may be in computer-readable form; in a Digital Portfolio, all artifacts have been transformed into computer-readable form. An electronic portfolio is not a haphazard collection of artifacts (i.e., a digital scrapbook or a multimedia presentation) but rather a reflective tool that demonstrates growth over time (Barrett, 2000). The National Learning Infrastructure Initiative (NLII, 2004) defined electronic portfolio as: a collection of authentic and diverse evidence, drawn from a larger archive representing what a person or organization has learned over time on which the person or organization has reflected, and designed for presentation to one or more audiences for a particular rhetorical purpose.

Cooper \& Love (2001) defined portfolio in general as an organized compilation of artifacts that demonstrates learning and achievement and includes exegesis that articulates relevance and meaning. While Barrett (2005) defined electronic portfolio as the uses of electronic technologies as a container, allowing students/teachers to collect and organize portfolio artifacts in many media types (audio, video, graphics, text); and using hypertext links to organize the material, connecting evidence to appropriate outcomes, goals or standards. 
In overall, types of information might be stored in electronic portfolio, may shape its definition, Banks (2004) stated types of information that electronic portfolio can contain:

Table 1: Electronic portfolio content (Banks, 2004. P. 6)

\begin{tabular}{|c|c|}
\hline Type & Examples \\
\hline Coursework & $\begin{array}{l}\text { Ranging from brief notes to extensive } \\
\text { assignments. May be in any medium, for } \\
\text { example, text, images, sound, video. May } \\
\text { be school homework, college assignments. }\end{array}$ \\
\hline Assessment work & $\begin{array}{l}\text { May include diagnostic, formative and } \\
\text { summative assessments. }\end{array}$ \\
\hline Other pieces of work or 'artifacts' & $\begin{array}{l}\text { For example, presentations, job or course } \\
\text { applications, CVs. }\end{array}$ \\
\hline $\begin{array}{l}\text { Achievement of individual learning } \\
\text { outcomes }\end{array}$ & May be formally or informally recorded \\
\hline $\begin{array}{l}\text { Aggregated records of achievement, } \\
\text { accreditation and credit towards awards }\end{array}$ & $\begin{array}{l}\text { Qualifications, awards (and credits } \\
\text { towards awards), certificates, completion } \\
\text { of courses. }\end{array}$ \\
\hline Evidence for assessment & $\begin{array}{l}\text { Including evidence for assessment of prior } \\
\text { learning }\end{array}$ \\
\hline Planning and reflection & $\begin{array}{l}\text { Journal entries, learning agreements, } \\
\text { personal development plans, individual } \\
\text { learning plans. }\end{array}$ \\
\hline Notes and annotations on other entries. & $\begin{array}{l}\text { Formal or informal: made by the learner, } \\
\text { or by teachers, mentors. Including } \\
\text { verification of entries. }\end{array}$ \\
\hline Skills and competencies & $\begin{array}{l}\text { Taken from to a particular framework, for } \\
\text { example, for a job, or informally recorded }\end{array}$ \\
\hline Outcomes of appraisals, interviews, etc. & $\begin{array}{l}\text { With tutor, employer, for example. } \\
\text { Self-assessments and appraisals. } \\
\text { Peer-assessments and appraisals }\end{array}$ \\
\hline Images captured on the move & $\begin{array}{l}\text { Mobile devices, such as phones, can be } \\
\text { used to capture and annotate images for an } \\
\text { e-portfolio. }\end{array}$ \\
\hline Links between entries & $\begin{array}{l}\text { Pieces of work contributing to an award: } \\
\text { planning to achieve particular skills, etc. }\end{array}$ \\
\hline Entries shared with peers & $\begin{array}{l}\text { E-portfolios can support peer group } \\
\text { earning, with shared assignments, and }\end{array}$ \\
\hline
\end{tabular}


\begin{tabular}{|l|l|}
\hline & $\begin{array}{l}\text { commentary on each other's work and } \\
\text { ideas. }\end{array}$ \\
\hline
\end{tabular}

The definition most likely for what the researcher finds out is that electronic portfolio is a web-based container which allows archiving, linking, collaborating, storing, and publishing student's work.

\section{Purposes of electronic portfolio:}

Types of electronic portfolios are different mainly in the area to which they are related according to the purposes of it. Electronic portfolios can be: as an assessment tool, for marketing or employment, and to document the growth for learners. Figure 1 presents Barrett (2005) representation for an assessment for learning continuum.

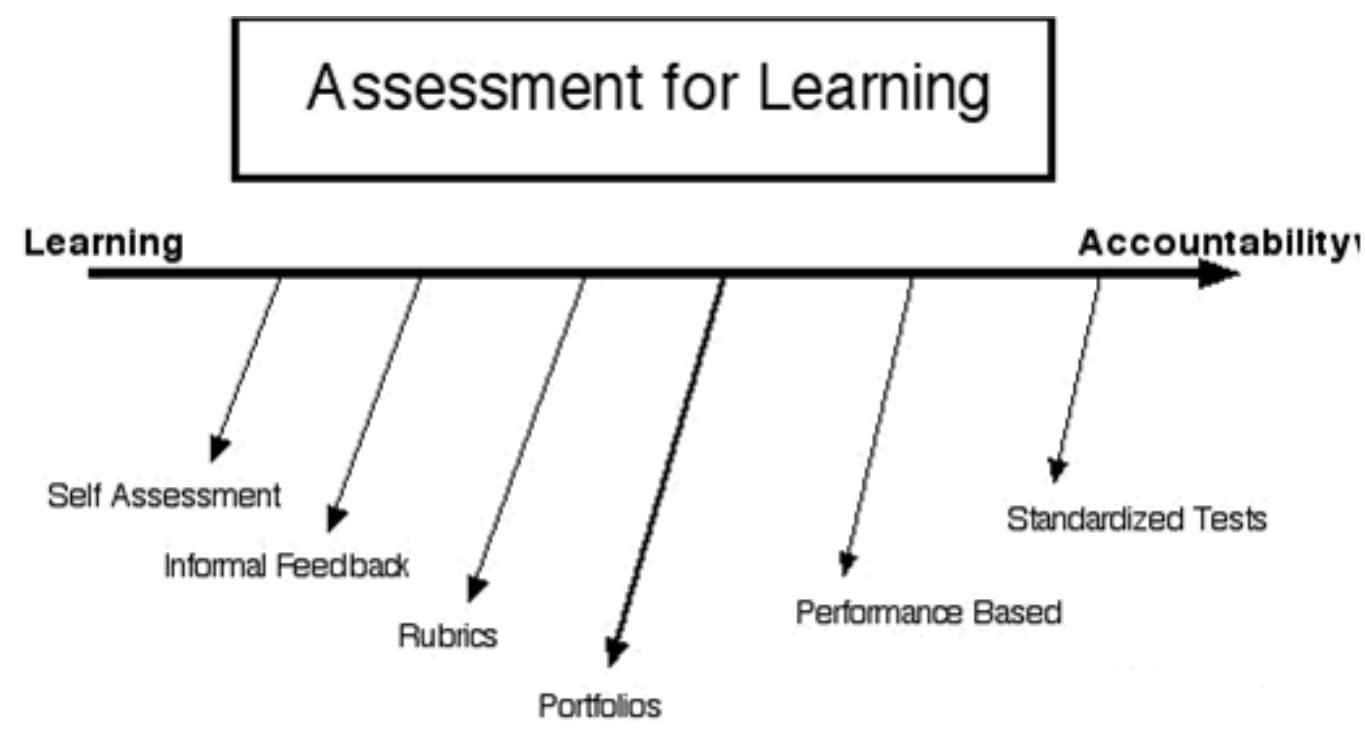

Figure (1): assessment for learning continuum Barrett (2005) P. 6

The main purposes of electronic portfolio are to serve as a container for the artifacts, selected for representing the learners' growth, skills and products. Wolf \& Dietz (1998) stated three purposes for portfolio according to its models: 1) Learner Portfolio 2) Assessment Portfolio, and 3) Employment Portfolio. Where Learner portfolios are personalized collection of teachers work and the main purpose is to advance teachers' learning and setting a reflection and variety of information that reflect the development of their work and their learning. Assessment portfolios are selective collection of teacher work and standardized assessments containing samples of teacher 
work. The primary purpose of this type of portfolio is to evaluate teacher performance. Employment portfolios are customized and attractive collection of information given by teachers to prospective employers; these portfolios contain generally a résumé and certificates.

\section{Types of electronic portfolio:}

There are different types of portfolio including assessment, employment, learning, and teaching portfolios, the formats depend on the purpose for which it is developed (Bhattacharya and Hartnett. 2007), three types of portfolio are often described: a 'learning' portfolio which documents a student's learning over time, a 'credentials' portfolio for registration/certification purposes, and 'showcase portfolio' for applying for jobs. (Duffy, Anthony, and Vickers, 2010), while Duffy et al (2010) mentioned that Nairn et al. (2006, p.1520) identify nine different types of portfolio based on the definition of a portfolio as 'a record of learning that focuses on a student's work and his/her reflection on that work'. But the most commonly electronic portfolios created by students, mentioned in Chang, Tseng, Yueh, and Lin (2011), are combination-based, content item-based, work-based, course unit-based, and time-based. The combination-based type incorporates the advantages of other tabulation types, while the content item-based and work-based types are better for clearly classifying data and step-by-step organization of it.

When determining the type of portfolio to be purchased, adapted, or developed, the institution must question the very nature of their electronic portfolio and can be an individualized self-assessment tool that is not constrained by student learning outcomes or, rather, a powerful piece of the assessment equation that links artifacts and reflections to learning goals and objectives. (Buzzetto-More \& Alade. 2008) 
Portfolios are useful in educational contexts for both summative and formative purposes (Cooper \& Love, 2001): 1) Summative portfolios focus on learning outcomes and contain evidence that shows the range and extent of a student's skills. A summative portfolio demonstrates learning outcomes rather than the process of learning. If the intention is to assess a student's skills or knowledge then the assessment is summative, and 2) The main role of a formative portfolio is to show the processes of learning in which a student has engaged. If assessment is concerned with learning process, the assessment should be formative.

Summative portfolio-based assessment has three main distinct forms; the competency based portfolio, the negotiated learning portfolio, and the biographic profile, or record of achievement. The main forms of portfolio are: 1) The competency-based or outcomes-based portfolio, 2) The negotiated learning portfolio, 3) The biographic portfolio as a record of achievement, and 4) The formative portfolio.

\section{Electronic Portfolio Components:}

An electronic portfolio is seen as comprehensive enough to include any piece of information about the student. Therefore there are many types of information components that could be included in an e-portfolio reflecting the person's accomplishments. For instance, work achievements might be included like; letters of recognition, awards, and certificates. Others could be concerned with professional and academic accomplishments, such as journal entries, articles, manuals, projects, courses descriptions, samples of effective and reflective writing, and significant papers. Eportfolios can also include artistic professions like artistic performances and writing stories. Research record is significant as well to be mentioned in e-portfolios, for example: case studies, evidence of data collected and evaluation form all 
practicum/field experiences. Resumes, professional correspondence and letters of reference add more specific details about the person's career.

\section{Electronic portfolio advantages and disadvantages:}

The advantages of electronic portfolio are beyond educational use, it can be selectively accessed by other interested parties like employers for instant. McNaught, Lam, \& Chan, present the strengths and weaknesses of electronic portfolio according to its types:

Table 2: Electronic Portfolios: strengths and weaknesses (McNaught, Lam, \& Chan, 2009, P. 11).

\begin{tabular}{|c|c|c|c|}
\hline $\begin{array}{c}\text { Type of } \\
\text { ePortfolio }\end{array}$ & Purpose & Strengths & Potential weaknesses \\
\hline Assessment & $\begin{array}{l}\text { Assessing and } \\
\text { evaluating } \\
\text { products and/or } \\
\text { process }\end{array}$ & $\begin{array}{l}\text { Learners can use detailed } \\
\text { portfolio requirement criteria to } \\
\text { regulate learning and assess } \\
\text { progress as they complete } \\
\text { assignments. }\end{array}$ & $\begin{array}{l}\text { The compilation of artifacts } \\
\text { and preparation of reflective } \\
\text { writing can be time-consuming } \\
\text { and problematic. }\end{array}$ \\
\hline $\begin{array}{l}\text { Presentation/ } \\
\text { Showcasing }\end{array}$ & $\begin{array}{l}\text { Presenting } \\
\text { oneself }\end{array}$ & $\begin{array}{l}\text { Learners can make use of } \\
\text { computer tools to create } \\
\text { presentations and showcase } \\
\text { their achievements. }\end{array}$ & $\begin{array}{l}\text { Students have to gain access to } \\
\text { a computer and have a } \\
\text { reasonably competent level of } \\
\text { IT skills. }\end{array}$ \\
\hline Learning & $\begin{array}{l}\text { Assisting } \\
\text { learning }\end{array}$ & $\begin{array}{l}\text { Students can make full use of } \\
\text { the learning materials that are } \\
\text { created in an electronic format } \\
\text { and they can access the } \\
\text { ePortfolio from any networked } \\
\text { computer. }\end{array}$ & $\begin{array}{l}\text { There is a possible duplication } \\
\text { with the paper system in } \\
\text { formal education. }\end{array}$ \\
\hline $\begin{array}{l}\text { Personal } \\
\text { development } \\
\text { planning } \\
(\mathrm{PDP})\end{array}$ & $\begin{array}{l}\text { Planning } \\
\text { development }\end{array}$ & $\begin{array}{l}\text { Students and tutors work } \\
\text { together to set academic or/and } \\
\text { non-academic learning } \\
\text { outcomes. Student progress can } \\
\text { be regularly monitored through } \\
\text { the ePortfolio system to detect } \\
\text { competence. The context and } \\
\text { process of learning can be } \\
\text { shared and reviewed. Through } \\
\text { reflections, students are } \\
\text { supported for their engagement } \\
\text { in learning. }\end{array}$ & $\begin{array}{l}\text { There is a financial and } \\
\text { resource implication for setting } \\
\text { up the system. Staff and } \\
\text { students may not familiar with } \\
\text { using the system. Training and } \\
\text { monitoring the system are an } \\
\text { investment of time and money. } \\
\text { Students may not like to do } \\
\text { reflections if awards or marks } \\
\text { are not available. Extra time } \\
\text { and careful planning of the } \\
\text { system are likely needed. }\end{array}$ \\
\hline Teamwork & $\begin{array}{l}\text { Collecting, } \\
\text { sharing and } \\
\text { reflecting on } \\
\text { artifacts }\end{array}$ & $\begin{array}{l}\text { There are potential value-added } \\
\text { features such as being flexible, } \\
\text { searchable, transferable and } \\
\text { having easy access. }\end{array}$ & $\begin{array}{l}\text { Students who are not fully IT- } \\
\text { literate may take a long time to } \\
\text { become familiar with the } \\
\text { system and there is a } \\
\text { possibility of overlapping with } \\
\text { other strategies for teamwork. }\end{array}$ \\
\hline
\end{tabular}


Electronic portfolios focus more on 'authentic learning experiences' that reflect real-world's overall life. It help students document their work, electronic portfolios help provide better way of measuring students learning that would be more accurate and electronic portfolios help educational institutions communicate with 'today's undergraduates' whose life is based more on technology and internet. (Reese and Levy. 2009)

Duffy, Anthony and Vickers (2010) summarized those advantages and disadvantages of Electronic portfolios, some of these advantages are:

1. The links are an advantage in a range of materials, with ease of access to the linked resources and the richness of the resulting student portfolio, but the student focus group was not convinced of the added value to what might be termed 'hypertext learning style'.

2. Specific e-portfolio packages provide template tools that may encourage a better output; for example, a CV builder. There are also tools and templates that may aid reflective practice; for example, the templates for skills analysis and training needs

3. E-portfolio tools and the capacity of some packages to produce different portfolios may be an advantage in meeting various distinct objectives of portfolio production, including evidence of achievement and of reflection and of progress.

4. Specific e-portfolio packages may have an additional advantage in the generation of web folios (portfolios on the web) and different versions of portfolios for different audiences; however, students have to be persuaded these are necessary.

5. Some PDP e-portfolio packages also support placement management but only one eportfolio package we found was specifically designed both for placement management and placement portfolio building.

While the disadvantages where: 
1) There may be cost, buy-in and take-up problems of e-portfolios for placement where they are not in widespread and successful use in a university before their introduction to portfolio assessment in placement.

2) E-portfolios may have practical problems for some placements, owing to remote access to network drives and employer 'buy-in'.

3) Template-based e-portfolios may become too restrictive for many students as they get more skilled at writing reflectively and at constructing portfolios. I

4) Students may find it unwieldy to use the e-portfolio package for placement if it gets heavily populated with 'assets' as part of a progress file from school through university to the workplace. Generic e-portfolios have to be populated with assets or attributes that have to be drawn down in different combinations on different forms for different purposes and there is some evidence that students do not find this sufficiently flexible. They prefer to use common tools to construct what they want when they want it. These tools are easier to use remotely and where no local area networks are accessible. The materials produced by common tools may be easier for the author to retain ownership of, post-university.

5) If the institution has decided to implement a system to support PDP, then it is sensible to consider using it in placement; however, students appear to value the paper product, and some employers will only look at a paper version, or at least one that can be simply emailed.

\section{Tools and Open sources for electronic portfolios:}

Open sources may give a solution; they can be integrated in Learning Management Systems (LMS), some of these open sources are worldwide adopted by universities, such as: 
Sakai: The Sakai Project began in 2004 when Stanford, Michigan, Indiana, MIT and Berkeley, US, began building a common Courseware Management System and now it is the choice of over 160 educational institutions. The software enables users to design, publish, share and view portfolios of work. It can create structures to help users reflect on their learning and development. Summative feedback and export report facilities are also included in the system (http://sakaiproject.org)

Mahara: Funded by New Zealand's Tertiary Education Commission's elearning Collaborative Development Fund, Mahara was a collaborative venture in 2006, involving Massey University, Auckland University of Technology, The Open Polytechnic of New Zealand, and Victoria University of Wellington. It enables users to collect, reflect on and share achievements and development online. It features a weblog, résumé builder and social networking system, connecting users and creating online learner communities. The system can be used with Moodle. The software was the winner of New Zealand Open Source Awards 2008 ( http://mahara.org/)

Elgg: is an award-winning open source social networking engine that provides a robust framework on which to build all kinds of social environments, from a campus wide social network for your university, school or college or an internal collaborative platform for your organization through to a brand-building communications tool for your company and its clients (http://elgg.org)

The table below, shows the most recommended products that help in creating electronic portfolios (Himpsl and Baumgartner. 2009)

Table 3: The most recommendable products

\begin{tabular}{|l|l|c|c|}
\hline \multicolumn{1}{|c|}{ Product } & \multicolumn{1}{|c|}{ Provider } & Type & license \\
\hline Drupal ED & Funnymonkey & $\mathrm{I}$ & OS \\
\hline Elgg & Curverider & $\mathrm{A}$ & OS \\
\hline Epsilen & BehNeem LLC & $\mathrm{M}$ & PU \\
\hline Exabis & Exabis Internet Solutions & $\mathrm{L}$ & OS \\
\hline
\end{tabular}




\begin{tabular}{|l|l|c|c|}
\hline Factline & Factline Webservices GmbH & I & P \\
\hline Fronter & Fronter International & L, I & U \\
\hline Mahara & eCDF New Zealand & M & OS \\
\hline Movable Type & Six Apart & I & OS \\
\hline PebblePad & Pebble Learning Ltd & M & PU \\
\hline Sakai & The Sakai Foundation & L, I & OS \\
\hline Taskstream & Taskstream Inc & M, I & PU \\
\hline Wordpress & Aoutomattic & A & OS \\
\hline
\end{tabular}

Key to column "type": - M: E-Portfolio-Management-Software products deliberately offered to institutions as E-Portfolio software) - L: LMS/LCMS with integrated E-Portfolio functions ("learning platform" with E-Portfolio elements) • I: integrated systems respectively software families

(various CMS with rather "indirectly" possible Portfolio functions) • A: other systems, respectively kinds of software

Key to column "license": • OS: open-source • P: commercial with all-inclusive offer • U: commercial with licenses per user $\bullet \mathrm{PU}$ : commercial with a combination of $\mathrm{P}$ and $\mathrm{U}$

\section{Electronic Portfolio and Employability:}

Employers seeks the most convenient manpower, electronic portfolio can represents what the graduates' skills are. In Canada and the USA, individual student portfolios are the preferred methods for recording employability skills (Little, 2003). Universities would favor better information about what employers' thoughts about electronic portfolios, what they would like as evidence about the students skills, how employers think they should be structured and the formats they would prefer. Some universities offer web-based portfolios to students so they can manage their own portfolios, but to be effective students need guidance from careers services and/or academic staff to complete these (Precision Consultancy, 2007).

\section{Conclusions:}

By way of concluding, it can be said that e-portfolios serve as an alternative evaluation of the learners' educational improvements. In other words, they include learners' academic accomplishments and learning achievements; which, on their turn, reflect the kind of skills that have been acquired by the learner throughout the educational process. Thus, educators will be able to evaluate their students and come up with an almost detailed documentary' of the learner's outcomes. 
E-portfolios can also be helpful in searching for jobs and even in looking for employees. Since an e-portfolio includes information about the professional skills of the learner, it would work as a representative summary of the job seeker. However, there must be a sense of cooperation between the learning management systems and employers, in the sense that e-portfolios will be used as web-based sources through the open sources; and then employers will have the opportunity to search the web looking for their man power.

\section{- REFERENCES:}

1. Alvarez, A. R., \& Moxley, D. P. (2004). The student portfolio in social work education. Journal of Teaching in Social Work, 2 (1/2), 87-104.

2. Banks, Bob. (2004). E-portfolios: their use and benefits. A White Paper. Version 1.1. December 2004. Available at: http://www.eife-l.org/publications/eportfolio/documentation/doc/fd

3. Barrett, Helen (2000, April). Create Your Own Electronic Portfolio. Learning \& Leading with Technology Vol. 27, No. 7, pp. 14-21

4. Barrett, Helen C. (2005) Researching Electronic Portfolios and Learner Engagement. Available at: http://electronicportfolios.com/portfolios/JAALREFLECT3.pdf

5. Bhattacharya, Mafhumita \& Hartnett, Maggie. (2007). E-Portfolio Assessment in Higher Education. $37^{\text {th }}$ ASEE/IEE Frontiers in Education Conference, October 1013, 2007, Milwaukee, WI. P. 19-24 http://fie-conference.org/fie2007/papers/1720.pdf

6. Buzzetto-More, N., \& Alade, A. (2008). The Pentagonal E-Portfolio Model for Selecting, Adopting, Building and Implementing an E-Portfolio. Journal of 
Information Technology Innovations in Practice. Volume 7, (pp. 45-70). Retrieved from: http://www.jite.org/documents/Vol7/JITEv7IIP045-070More383.pdf

7. Chang, Chi-Chen, Tseng, Kuo-Hung, Yueh, Hsiu-Ping, and Lin, Wei-Chien (2011). Consideration factors and adoption of type, tabulation and framework for creating e-portfolios. Computer \& Education 56 (2011) 452-465

8. Cooper, T \& Love, T. (2001). Online portfolios: Issues of assessment and pedagogy. In P. Jeffrey (Ed.),AARE 2001: Crossing borders: New frontiers of educational research (pp. 417-426). Coldstream, Victoria:AARE Inc. Retrieved from:

http://www.love.com.au/PublicationsTLminisite/2001/2001\%20Aare\%20\%200nlin e_portfolios_TC\&TL.htm

9. Duffy, Katherine, Anthony, Denis, and Vickers, Francesca (2010), Are Electronic Portfolios an Asset to Learning in Placement? Learning and Teaching in Higher Education. Issue 4-2, (pp. 90-113). Retrieved from:

http://insight.glos.ac.uk/tli/resources/lathe/Documents/issue\%204-

\section{2/articles/duffy.pdf}

10. Franklin, Teresa. (2005). Seeking the Perfect Electronic Portfolio Solution: A Case Study. Proceedings of Society for Information Technology \& Teacher Education International Conference 2005 (pp. 84-87). Chesapeake, VA: AACE. Retrieved from: http://center.uoregon.edu/conferences/ISTE/uploads/NECC2005/KEY 7610066/Fr anklin_FranklinNECC_2005_RP.pdf

11. Hampsl, K., and Baumgartner, P. (2009). Evaluation of E-Portfolios Software. iJET - Volume 4, Issue 1, March 2009. Pp. 16-22. article was modified from a presentation at the International Conference of Interactive Computer Aided Learning ICL2008, September 24 - 26, 2008 in Villach, Austria. Manuscript 
received 02 February 2009. Published as submitted by the authors. http://www.ijet.org

12. Heath, M. S. (2004). Electronic Portfolios: A Guide to Professional Development and Assessment. Worthington, Linworth Publishing, Inc.

13. Little B. 2003. International Perspectives on Employability, a Briefing paper for the Higher Education Academy. Higher Education Academy. Available at: http://www.heacademy.ac.uk/resources/detail/employability/employability524

14. McNaught, C., Lam, P., \& Chan, Y. M. (2009). Development of a conceptual framework for articulating experiential learning using ePortfolios. Working Paper 4. Hong Kong: Centre for Learning Enhancement and Research. The Chinese University of Hong Kong. Retrieved from:

http://www.cuhk.edu.hk/clear/research/WP4_McNLC_2009.pdf

15. Precision Consultancy. (2007), Graduate employability skills: Prepared for the Business, Industry and Higher Education Collaboration Council, Canberra: Commonwealth of Australia.

http://www.dest.gov.au/NR/rdonlyres/E58EFDBE-BA83-430E-A5412E91BCB59DF1/20214/GraduateEmployabilitySkillsFINALREPORT1.pdf

16. Reese, Michael, and Levy, Ron (2009). “Assessing the Future: E-Portfolio Trends, Uses, and Options in Higher Education" (Research Bulletin, Issue 4). Boulder, CO: EDUCAUSE Center for Applied Research, 2009, available from http://www.educause.edu/ecar.

17. Schatz, M. S., \& Simon, S. (1999). The portfolio approach for generalist social work practice: A successful tool for students in field education. Journal of Baccalaureate Social Work, 5(1), 99-107. 
18. Schatz, M. S. (2004). Using portfolios: Integrating learning and promoting for social work students. Advances in Social Work, 5(1), 105-123.

19. The National Learning Infrastructure Initiative (NLII, 2004), Annual Review.

Effective teaching and learning is, first and foremost, about the learner. Available at: http://net.educause.edu/ir/library/pdf/NLI0405.pdf

20. The Pentagonal E-Portfolio Model for Selecting,Adopting, Building, and Implementing an E-Portfolio Nicole Buzzetto-More and Ayodele Alade University of Maryland Eastern Shore, Princess Anne, MD, USA 7,2008.

21. Tosh, David and Wodmuller, Ben (2004). Creating of a learning landscape: weblogging and socialnetworking in the context of e-portfolios. Available at: http://projects.cbe.ab.ca/central/altudl/FILES/Creating_a_Learning_landscape_blog s.pdf

22. Wolf, Kenneth and Dietz, Mary. (1998). "Teaching Portfolios: Purposes and Possibilities." Teacher Education Quarterly(Winter 1998): 9-22. Retrieved from: http://www.teqjournal.org/backvols/1998/25_1/1998v25n103.PDF 